\title{
Trends and Patterns of Foreign Direct Investment in India (FDI)
}

\author{
S. V. Bharati*, P. V. Karale and R. V. Chavan \\ Department of Agricultural Economics, College of Agriculture, Parbhani, India \\ *Corresponding author
}

\section{A B S T R A C T}

\begin{tabular}{l} 
Key w o r d s \\
Foreign Direct \\
Investment (FDI), \\
India, \\
Foreign investment \\
\hline Article Info \\
\hline $\begin{array}{l}\text { Accepted: } \\
26 \text { April } 2020 \\
\text { Available Online: } \\
\text { 10 May 2020 }\end{array}$ \\
\hline
\end{tabular}

Investment is an important concept for growth and prosperity of any economy. Domestic investment and foreign investment both are equally important. Domestic investment may lead to the creation of domestic savings, consumption and employment whereas foreign investment can decrease the gap in domestic saving. The study was undertaken with the objective to examine the trends and patterns of foreign direct investment in India. The descriptive design had been adopted for the study purpose using secondary data. Statistical tools such as Coefficient of variation $(\mathrm{C} . \mathrm{V})$, average, and percentage and distribution theory were applied to achieve the results. The data was taken for the period of 2001 to 2015. The results of the study highlighted the inflow of FDI Sector wise, Country wise and RBI region wise in India during the study period. Among all the top sectors in India, investments in service sector were more from FDI inflow which is $28 \%$ as compared to other sectors. Mauritius was having less coefficient of variation near to $24 \%$ which shows that Mauritius was the most consistent country investing in India as compared to other countries. It was revealed that Hyderabad was one among those RBI regional offices to be trusted for expanding FDI in India.

\section{Introduction}

One of the most striking developments during the last two decades is in the spectacular growth of FDI (Foreign Direct Investment) in the global economic landscape. Foreign direct investment (FDI) is an integral part of an open and effective international economic system and a major catalyst to development. Yet, the benefits of FDI do not accrue automatically and evenly across countries, sectors and local communities. National policies and the international investment architecture matter for attracting FDI to a larger number of developing countries and for reaping the full benefits of FDI for development.

In India role of FDI was first introduced by then finance minister Dr. Manmohan Singh in 1991 in the form of Foreign Exchange Management Act which lead to increase in the 
domestic capital cash inflows in the country and this will help in economic growth of the country. The importance of FDI has grown considerably in Indian economy day by day. After liberalization its role has changed significantly. Earlier the amount of FDI was low conforming to some selected sectors but now the inflow of FDI has grown tremendously and almost in all the sectors of the economy.

The study was undertaken with broad objectives such as to know the total inflow of FDI in India, identify the inflow of FDI from various countries, analysis of distribution of investments of FDI in various sectors and to check the consistency of investments of various countries and various RBI regions through FDI in India.

\section{Materials and Methods}

To achieve the results of the objectives under study the following functional analysis was applied to the data.

\section{Linear trend}

Whenever it is apparent that the time series is moving up or down every year by a steady value,

$Y_{t}=a+b x$

Where,

$Y_{t}=$ trend value

$\mathrm{a}=$ trend value in the year of the origin

$\mathrm{b}=$ annual increment

$\mathrm{X}=$ time in years

The linear trend equation is similar to the linear regression equation. The procedure of computing and interpretation of $a$ and $b$ are similar to the regression analysis.

\section{Coefficient of variation}

The consistency of players can be found using coefficient of variation. According to Prof. Karl Pearson who suggested C.V. is the percentage variation in the mean and standard deviation being considered as the total variation in the mean.

For comparing the variability of two or more series coefficient of variation is calculated. The series having greater C.V. is said to be more variable than the other and the series having lesser C.V. is said to be more consistent. Coefficient of variation is calculated as follows

Coefficient of Variation (C.V.) $=100 x^{\frac{\sigma}{\bar{x}}}$

Coefficient of Variation (C.V.): 100 times the coefficient of dispersion based upon the standard deviation is called Coefficient of Variation (C.V.).

\section{Results and Discussion}

\section{Trend of GDP and FDI}

The data for the period 2000-01 to 2014-15 was analyzed and presented in table 1 . It was observed from the table that the GDP was increasing in order while FDI were somewhat fluctuating (increasing and decreasing order) but it was noted that the FDI was at highest point during the period 2011-12 and 2014-15.

The graph shows that, there exist increasing trend during the period 2006-07 to 2014-15 with slight fluctuations. The highest rate of FDI inflow was during the year 2011-12 and 2014-15.while the trend line of GDP shows the steady growth over the given period.

\section{Sector wise distribution of FDI}

The table 2 Shows the splitting of investment of overall FDI in various sectors in India 
which given under the particular column in table and corresponding pie chart has been plotted to analyse the Sector wise percentage distribution of FDI in various sector.

It was highlighted from table and graph that the service sector contributes higher share i.e. 28 per cent (Rs.204169 crore) of total FDI than any other sector in India and other sectors contributes

\section{Coefficient of Variation of FDI inflow from the various countries}

Consistency of the top investing countries in India was fond out by using coefficient of Variation. The country with less coefficient of variation is more consistent country and the country with large coefficient of variation is less consistent. The results are listed in table and the coefficient of variation has been calculated as shown in table 3 . It is observed from the table that, among the top investing countries in India, U.K. has highest coefficient of variation which is 86 per cent and it indicates that there is very high variation in investments from U.K. as compared to other countries. Mauritius has less coefficient of variation near to 24 per cent which shows that Mauritius is most consistent country investing in India.

\section{Coefficient of Variation of FDI inflow among the RBI's Regional offices}

Consistency of the investment under the RBI's regional offices in India was found out by using Coefficient of Variation. The region with less coefficient of variation is more consistent region and the region with large coefficient of variation is less consistent .The results are listed in table and the coefficient of variation has been calculated as shown in table 4. It is observed from table that, among the RBI regional offices Bhubaneswar has got the highest coefficient of variation i.e.105 per cent which shows that the region is less reliable in terms of investment.

\section{Table.1 The trend of GDP and FDI}

(Rs. crore)

\begin{tabular}{|c|c|c|}
\hline Year & GDP & TOTAL FDI INFLOWS \\
\hline 2000-01 (April- March) & $2,000,743$ & 10,733 \\
\hline 2001-02 (April- March) & $2,175,260$ & 18,654 \\
\hline 2002-03 (April- March) & $2,343,864$ & 12,871 \\
\hline 2003-04 (April- March) & $2,625,819$ & 10,064 \\
\hline 2004-05 (April- March) & $2,971,464$ & 14,653 \\
\hline 2005-06 (April- March) & $3,390,503$ & 24,584 \\
\hline 2006-07 (April- March) & $3,953,276$ & 56,390 \\
\hline 2007-08 (April- March) & $4,582,086$ & 98,642 \\
\hline $\mathbf{2 0 0 8 - 0 9}$ (April- March) & $5,303,567$ & 142,829 \\
\hline 2009-10 (April- March) & $6,108,903$ & 123,120 \\
\hline 2010-11 (April- March) & $7,248,860$ & 97,320 \\
\hline 2011-12 (April- March) & $8,391,691$ & 165,146 \\
\hline 2012-13 (April- March) & $9,388,876$ & 121907 \\
\hline 2013-14 (April- March) & $10,472,807$ & 147,518 \\
\hline 2014-15 (April- March) & $11,345,056$ & 189,107 \\
\hline
\end{tabular}


Table.2 Distribution of FDI in various sectors

\begin{tabular}{|l|c|}
\hline \multicolumn{1}{|c|}{ Particular } & Total FDI \\
\hline Services Sector & 204169 \\
\hline $\begin{array}{l}\text { Construction Development } \\
\text { Townships, Housing, Built-Up Infrastructure }\end{array}$ & 67303 \\
\hline Computer Software \& Hardware & 71684 \\
\hline $\begin{array}{l}\text { Telecommunications (radio paging, cellular mobile, basic telephone } \\
\text { services) }\end{array}$ & 68954 \\
\hline Automobile Industry & 83393 \\
\hline Drugs \& Pharmaceuticals & 52696 \\
\hline Trading & 61992 \\
\hline Chemicals & 45477 \\
\hline Power & 35968 \\
\hline Hotel \& tourism & 36014 \\
\hline
\end{tabular}

Table.3 Coefficient of variation of FDI inflow from the various countries

\begin{tabular}{|l|c|c|c|c|c|c|c|c|c|}
\hline Year & Mauritius & Singapore & U.K. & Japan & U.S.A. & Netherlands & Germany & Cyprus & France \\
\hline $\mathbf{2 0 0 6 - 0 7}$ & 28759 & 2662 & 3861 & 8389 & 2905 & 266 & 382 & 540 & 1174 \\
\hline $\mathbf{2 0 0 7 - 0 8}$ & 44483 & 12319 & 4377 & 4690 & 2780 & 3385 & 3336 & 2075 & 1039 \\
\hline $\mathbf{2 0 0 8 - 0 9}$ & 50794 & 15727 & 8002 & 3840 & 3922 & 5983 & 1889 & 2750 & 1133 \\
\hline $\mathbf{2 0 0 9 - 1 0}$ & 49633 & 11295 & 9230 & 3094 & 4283 & 7728 & 5670 & 2980 & 3017 \\
\hline $\mathbf{2 0 1 0 - 1 1}$ & 31855 & 7730 & 12235 & 7063 & 5353 & 5501 & 908 & 4171 & 3349 \\
\hline $\mathbf{2 0 1 1 - 1 2}$ & 46710 & 24715 & 36428 & 14089 & 5347 & 6698 & 7452 & 7722 & 3110 \\
\hline $\mathbf{2 0 1 2 - 1 3}$ & 51654 & 12594 & 5797 & 12243 & 3033 & 10054 & 4684 & 2658 & 3487 \\
\hline $\mathbf{2 0 1 3 - 1 4}$ & 29360 & 35625 & 20426 & 10550 & 4807 & 13920 & 6093 & 3401 & 1842 \\
\hline $\mathbf{2 0 1 4 - 1 5}$ & 55172 & 41350 & 8769 & 12752 & 11150 & 20960 & 6904 & 3634 & 3881 \\
\hline Mean & $\mathbf{4 3 1 5 7 . 7 8}$ & $\mathbf{1 8 2 2 4 . 1 1}$ & $\mathbf{1 2 1 2 5}$ & $\mathbf{8 5 2 3 . 3 3 3}$ & $\mathbf{4 8 4 2 . 2 2 2}$ & $\mathbf{8 2 7 7 . 2 2 2}$ & $\mathbf{4 1 4 6 . 4 4 4}$ & $\mathbf{3 3 2 5 . 6 6 7}$ & $\mathbf{2 4 4 8}$ \\
\hline S.D. & $\mathbf{1 0 3 4 7 . 7}$ & $\mathbf{1 3 0 0 4 . 0 9}$ & $\mathbf{1 0 3 9 5 . 7 1}$ & $\mathbf{4 1 0 8 . 8}$ & $\mathbf{2 5 6 7 . 6 6 9}$ & $\mathbf{6 1 2 0 . 9 7 5}$ & $\mathbf{2 6 3 0 . 1 5}$ & $\mathbf{1 9 4 8 . 1 9 9}$ & $\mathbf{1 1 4 0 . 8 1 3}$ \\
\hline c.v. & $\mathbf{2 3 . 9 7 6 4 3}$ & $\mathbf{7 1 . 3 5 6 5 3}$ & $\mathbf{8 5 . 7 3 7 8 1}$ & $\mathbf{4 8 . 2 0 6 4 9}$ & $\mathbf{5 3 . 0 2 6 6 7}$ & $\mathbf{7 3 . 9 4 9 6 3}$ & $\mathbf{6 3 . 4 3 1 4 6}$ & $\mathbf{5 8 . 5 8 0 7 1}$ & $\mathbf{4 6 . 6 0 1 8 4}$ \\
\hline
\end{tabular}


Table.4 Coefficient of variation of FDI inflow among the RBI's Regional offices

\begin{tabular}{|c|c|c|c|c|c|c|c|c|c|c|}
\hline $\begin{array}{l}\text { RBI's - Regional } \\
\text { Offices }\end{array}$ & $\begin{array}{c}2009- \\
10\end{array}$ & $\begin{array}{c}2010- \\
11\end{array}$ & $\begin{array}{c}2011- \\
12\end{array}$ & $\begin{array}{c}2012- \\
13\end{array}$ & $\begin{array}{c}2013- \\
14\end{array}$ & 2014-15 & Total & Mean & S.D. & C.V. \\
\hline Mumbai & 39409 & 27669 & 44664 & 47359 & 20595 & 38933 & 218629 & 36438.17 & 10294.5 & 28.25196 \\
\hline New Delhi & 46197 & 12184 & 37403 & 17490 & 38190 & 42252 & 193716 & 32286 & 13977.77 & 43.29359 \\
\hline Chennai & 4852 & 6133 & 7235 & 15252 & 12595 & 23361 & 69428 & 11571.33 & 7030.222 & 60.75551 \\
\hline Bangalore & 3653 & 6115 & 6711 & 5553 & 11422 & 21255 & 54709 & 9118.167 & 6480.776 & 71.07543 \\
\hline Ahmadabad & 3876 & 3294 & 4730 & 2676 & 5282 & 9416 & 29274 & 4879 & 2414.143 & 49.48027 \\
\hline Hyderabad & 5710 & 5753 & 4039 & 6290 & 4024 & 8326 & 34142 & 5690.333 & 1600.889 & 28.13348 \\
\hline Kolkata & 531 & 426 & 1817 & 2319 & 2659 & 1464 & 9216 & 1536 & 916.5684 & 59.67242 \\
\hline Kochi & 1038 & 1892 & 624 & 255 & 562 & 234 & 4605 & 767.5 & 624.1429 & 81.32154 \\
\hline Jaipur & 606 & 167 & 2274 & 1208 & 708 & 3237 & 8200 & 1366.667 & 1166.039 & 85.31991 \\
\hline Chandigarh & 255 & 2093 & 569 & 390 & 411 & 601 & 4319 & 719.8333 & 684.4994 & 95.09137 \\
\hline Bhopal & 808 & 1376 & 181 & 47 & 103 & 1418 & 3933 & 655.5 & 636.3115 & 97.07269 \\
\hline Panaji & 149 & 230 & 161 & 714 & 233 & 211 & 1698 & 283 & 214.0533 & 75.6372 \\
\hline Kanpur & 227 & 514 & 635 & 167 & 288 & 679 & 2510 & 418.3333 & 219.4572 & 52.45989 \\
\hline Bhubaneswar & 702 & 68 & 125 & 285 & 150 & 56 & 1386 & 231 & 244.8461 & 105.994 \\
\hline Guwahati & 51 & 37 & 5 & 27 & 4 & 29 & 153 & 25.5 & 18.32757 & 71.87284 \\
\hline
\end{tabular}

\section{TOTAL FDI INFLOWS(In cr Rs.)}

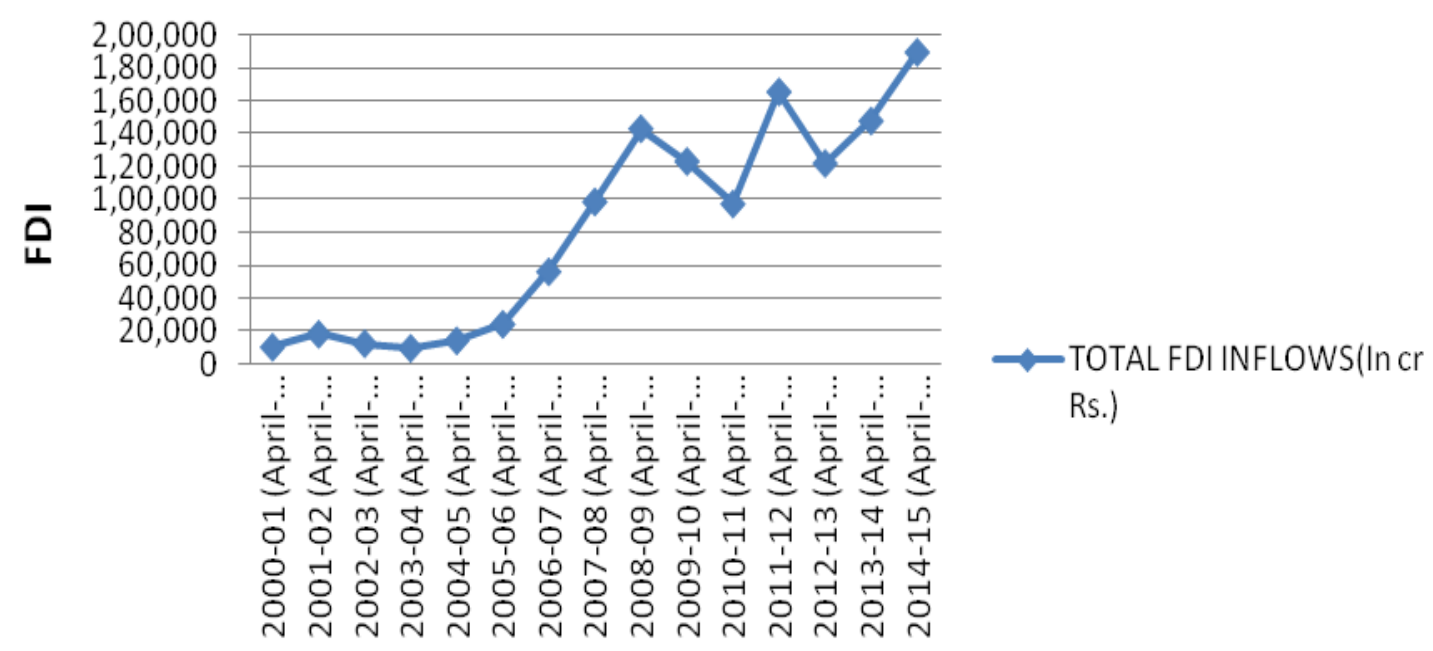

YEAR 

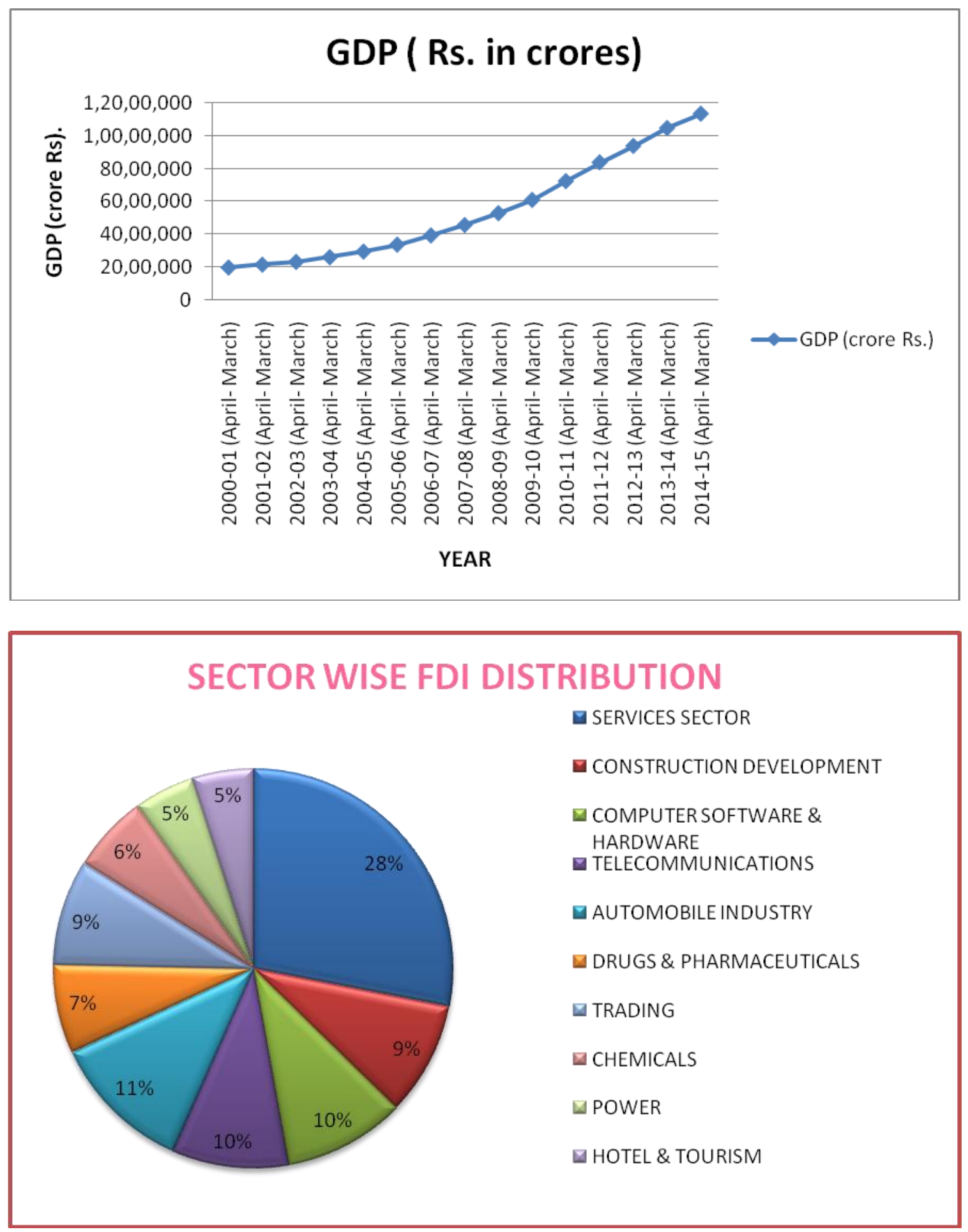

Hyderabad has less variation near to 28 per cent which indicates that, foreign investors clarifies view that Hyderabad is one among those RBI regional offices to be trusted for expanding their business in India.
It is concluded from the study undertaken that, the positive upward trend was observed in GDP of India over the period of study. In case of FDI there is increasing trend observed in FDI during the period of 2006-07 to201415 with slight fluctuations, Mauritius invests 
more in India as compared to other countries and U.S.A. invests very less in India.

In sector wise study it was seen that among all the top sectors in India, investments in service sector was more from FDI inflow which was 28 per cent as compared to other sectors. FDI inflow was negligible only 5 per cent of investments was done in power sector.

The study further concludes that in case of consistency in FDI, among the top investing countries in India, U.K. has highest coefficient of variation which is 86 per cent which shows there is very high variation in investments from U.K. in India as compared to other countries. Mauritius has less coefficient of variation near to 24 per cent which shows that Mauritius is most consistent country as compare to other countries.

The present study also concludes that among the RBI's regional offices in India, Bhubaneswar has highest coefficient of variation which is 105 per cent which shows very high variation in investments of inflow of FDI. Hyderabad has less coefficient of variation near to 28 per cent which shows that
Hyderabad is most consistent RBI's regional office as compare to other RBI's regional offices of RBI.

\section{References}

Hooda Sapna (2011). A Study of FDI and Indian Economy (Doctoral Thesis, National Institute of Technology, Haryana)

Kumar Gajendran, Lenin and Karthika S. (2010) Sectoral performance through inflows of foreign direct investment (FDI).

Bhavya Malhotra. (2014). Global Journal of Business Management and Information Technology by "Foreign Direct Investment: Impact on Indian" Volume 4(1) pp. 17-23.

Mahanta Devajit. (2012). Research Journal of Management Sciences "Impact of Foreign Direct Investment on Indian economy" Vol. 1(2), 29-31

Chalapati Rao, K.S., Biswajit Dhar. (2011) India's FDI Inflows: Trends and Concepts. Institute for Studies in Industrial Development (ISID).

\section{How to cite this article:}

Bharati, S. V., P. V. Karale and Chavan, R. V. 2020. Trends and Patterns of Foreign Direct Investment in India (FDI). Int.J.Curr.Microbiol.App.Sci. 9(05): 3002-3008.

doi: https://doi.org/10.20546/ijcmas.2020.905.356 